\title{
Allergy \& prehistory in Spanish written press
}

\section{Alergia \& pré-história na imprensa escrita espanhola}

\author{
Macarena Parejo CUÉLLAR ${ }^{1}$ (D) 0000-0002-5292-2731 \\ Daniel Martín PENA 1 (D) 0000-0003-2676-5821 \\ Agustín Vivas MORENO1 (D) 0000-0001-7571-126X
}

\begin{abstract}
News about science should never be treated as trivial matters. This article focuses on the topics of allergies and prehistory to analyze and compare the presence of these two areas in the Spanish written press. We performed documentary analysis of 141 news items and 150 units of analysis. We have also developed our own methodology. In this sense, the tool is divided into two blocks: the first part collects general data about the written media and the second assesses the excellence of the text and the information. Our work confirms the scarcity of information on both topics, their low media relevance, and a lack of any remarkable journalistic focus in terms of originality and creativity. In particular, we looked for items in the printed versions of the dailies EI Mundo, La Vanguardia, La Razón, El País, and EI ABC, ranked as the most widely read newspapers in the different editions of the Spanish General Media Report in 2018.
\end{abstract}

Keywords: Journalism. Scientific communication. Use of information.

\section{Resumo}

Notícias sobre ciência nunca devem ser tratadas como uma questão trivial. Este artigo enfoca dois tópicos, alergias e pré-história, para analisar e comparar a presença de matérias que tratem de assuntos relativos a essas duas áreas na imprensa escrita espanhola. Para tanto, realizou-se uma análise documental de 141 itens de notícias e 150 unidades de análise, além de uma metodologia própria ter sido desenvolvida. Nesse sentido, a ferramenta é dividida em dois blocos: a primeira parte coleta dados gerais sobre a mídia escrita e a segunda avalia o grau de excelência do texto e da informação. Este trabalho confirma a escassez de informações sobre ambos os tópicos, sua baixa relevância na mídia e a falta de um notável foco jornalístico em termos de originalidade e criatividade. Em particular, procurou-se por versões impressas dos diários El Mundo, La Vanguardia, La Razón, El País e El ABC, classificados como os jornais mais lidos nas diferentes edições do Spanish General Media Report no ano 2018.

Palavras-chave: Jornalismo. Comunicação científica. Uso da informação.

\section{Introduction}

"Everyone has the right freely to participate in the cultural life of the community, to enjoy the arts and to share in scientific advancement and its benefits" (Organizácion ..., 1948). The Declaration of Human Rights was proclaimed as an ideal for all people and it is a landmark document in history, supporting the importance of

\footnotetext{
1 Universidad de Extremadura, Facultad de Ciencias de la Documentación y la Comunicación, Departamento de Información y Comnunicación. Plazuela Ibn Marwan s/n., 06001 Badajoz, España. Correspondence to/Correspondencia para: M. P. CUÉLLAR. E-mail:<macarenapc@unex.es>.

Receveid on February 27, 2020 and approved on April 23, 2020.
}

Como citar este artigo/How to cite this article

Cuéllar, M. J.; Pena D. M.; Moreno A. V. Allergy \& prehistory in Spanish written press. Transinformação, v. 32, e200010, 2020. https://doi.org/10.1590/1678$9865202032 \mathrm{e} 200010$ 
scientific journalism. According to Elías (2008) and Grande et al. (2016), the concept "scientific journalism" is much more complex than science communication or outreach, as it requires a contextualization of the news items. The term shares the goals of developing a critical spirit and contributing to education, knowledge transfer, and social transformation (Parejo et al., 2018). Only in this way could the words of Nobel Prize winner Ramón y Cajal stop ringing true:"the carriage of Spanish culture is missing the wheel of science" (Calvo, 2015). This author explains that the task of the media and scientific journalism is to engage in the gigantic effort of prospective instruction with the educational system.

Scientific journalism began in the United States in the 1920s, when The New York Times introduced its first permanent section with information related to science (Ferrer, 2002). In Spain, the process began much later, in the 1980s, when scientific newspaper supplements became popular. In this period, scientific information in the Spanish press grew substantially in comparison to the publication of similar topics at the beginning and mid-20 th century. Dailies such as "La Vanguardia" started a process of change led by the journalist De Semir, who suggested the creation of a science supplement. The responsible for this turn, De Semir pushed for the creation of this space. "The solution was to create an additional Sunday supplement [...]. That is how the first science supplement of La Vanguardia came to be on October the 10th 1982" (Revuelta, 2011 p. 226). Several newspapers followed that decision (Fernández, 2005; De Semir, 2015).

Since this boom, many dailies have decided to get rid of such supplements, arguing that they prefer to publish scientific articles the day something happens, as "Le Monde" or "The New York Times" do. Addressing scientific news on a daily basis is a positive thing, its most important advantage being that readers do not get tired of excessive scientific information, as it happens with the supplements. Our current lifestyle does not allow so much time for a single thing. Thus, a small item inserted in the society page will be more widely read than the supplements (Elías, 2019).

The continued presence of this type of information might help educating citizens to understand the reality of shared knowledge. As Alcalde (2018) wrote, "science is a shared adventure". As Calvo (2015) reminds us, we have to realize that citizens are interested in science. The latest results of the survey on the social perception of science, published by the Spanish Science and Technology Trust (España, 2018) prove these affirmations: 16.3\% of citizens spontaneously mentioned science as a topic of interest in the media. Therefore, disseminating science in the media must be understood as a tool for cultural synthesis (López; Otero; Calvo, 2008).

Public health matters have slowly become more relevant in the public eye (Martínez; Saperas; Carrasco, 2019), and, as a result, health-related content in the written press has increased (Márquez, 2010). According to a report of the University of Granada, the dissemination of scientific content by the press can impact scientific research. In this study, $70.5 \%$ of researchers considered that disseminating their work to larger audiences had helped them advance in the scientific career, especially as newspapers reflect all the sociological, political, and cultural aspects of society (Krtalic; Hasenay, 2012) and can help the social sciences and the humanities study specific contexts.

Taking this contextualization into account (Canellas, 2016), there is a pressing need to study the ways in which science is presented in the written press nowadays. This is the main goal of this study, which also aims to complement and provide new data on the topic already discussed by a number of authors (Cassany; Cortiñas; Elduque, 2018). Researchers such as Rodríguez (2016), Alonso (2018), Alonso, Eleazar and Moreno, (2018), Bellón (2018), and Casino (2018), among others, have all studied in one way or another the influence that science has on the media and vice-versa, what role these play in raising awareness about scientific matters. Our study, therefore, tries to add a new contribution and provide a snapshot of the way two specific areas of knowledge are presented in the media. We will particularly focus on two topics that are relevant in each field: allergies and prehistory respectively. Studying such divergent topics will help us establish a comparative analysis between the two blocks. 


\section{Procedures and Methodology}

We designed a methodological resource to establish a comparison of both fields - allergies and prehistory - after quantitative and qualitative documentary analysis. A scorecard has been developed to analyze content according to several parameters. Piñuel (2002) calls this method "content analysis" and describes the set of interpretative procedures around communication products coming from previously registered unique communication processes. Berelson (1952) described this process as a research technique for the objective, systematic, and quantitative description of content, with the goal of interpreting the data. The tool is divided into two blocks. First, it collects general data about the written media and then, it assesses the text and information's degree of excellence (Chart 1).

Chart 1. General and specific aspects.

\begin{tabular}{|c|c|}
\hline & Provisional scorecard newspaper analysis \\
\hline & El País \\
\hline & ElMundo \\
\hline Newspaper & La Vanguardia \\
\hline & LaRazón \\
\hline & $E / A B C$ \\
\hline Date & From January $1^{\text {st }}$ to December $31^{\text {st }} 2018$ \\
\hline & Even \\
\hline & Odd \\
\hline & Catch line \\
\hline & Left side \\
\hline & Right side \\
\hline & Centre \\
\hline & Photograph \\
\hline Pages & Back page \\
\hline & Photograph \\
\hline & Full size \\
\hline & Half page \\
\hline & Upper part of the page \\
\hline & Middle of the page \\
\hline & Lower part of the page \\
\hline & International \\
\hline & National \\
\hline & Business \\
\hline & Culture \\
\hline & Work \\
\hline & Crime \\
\hline & Regional \\
\hline Section & Local \\
\hline & Sports \\
\hline & Education \\
\hline & Science \\
\hline & Religion \\
\hline & Society \\
\hline & Opinion \\
\hline & Family \\
\hline Editorial & \\
\hline & Less than a page \\
\hline & Full page \\
\hline Length & Two pages \\
\hline & Over two pages \\
\hline
\end{tabular}


Chart 1. General and specific aspects.

Provisional scorecard newspaper analysis

\begin{tabular}{|c|c|c|}
\hline \multirow{14}{*}{ Journalistic genre } & \multicolumn{2}{|l|}{ News } \\
\hline & \multirow{6}{*}{ Report } & Short \\
\hline & & In depth \\
\hline & & Interpretative \\
\hline & & Research \\
\hline & & Human Story \\
\hline & & Mixed \\
\hline & \multirow{3}{*}{ Interview } & Informative or statement \\
\hline & & Direct \\
\hline & & Indirect or reported \\
\hline & \multicolumn{2}{|l|}{ Chronicle } \\
\hline & \multirow{3}{*}{ Biographical } & Profile \\
\hline & & Sketch \\
\hline & & Obituary \\
\hline \multirow{22}{*}{ Photograph } & \multirow{3}{*}{ Size } & Small \\
\hline & & Medium \\
\hline & & Small \\
\hline & \multicolumn{2}{|l|}{ Author } \\
\hline & Caption & \\
\hline & \multirow{17}{*}{ Source } & Headshot \\
\hline & & Advertising \\
\hline & & Fashion \\
\hline & & Artistic \\
\hline & & Landscape and Nature \\
\hline & & Documentary \\
\hline & & Night \\
\hline & & Sports \\
\hline & & Submarine \\
\hline & & Journalistic \\
\hline & & Aerial \\
\hline & & Astronomical \\
\hline & & Scientific \\
\hline & & Photo Macrography \\
\hline & & Microscopic \\
\hline & & Graphs \\
\hline & & Illustrations \\
\hline \multicolumn{3}{|c|}{ Content Analysis } \\
\hline \multicolumn{3}{|l|}{ Short Review } \\
\hline \multirow{15}{*}{ Sources of information } & University & \\
\hline & Scientific Journals & \\
\hline & Museums & \\
\hline & Books & \\
\hline & \multirow{3}{*}{ Public research bodies } & CSIC \\
\hline & & Canarias Astrophysics Institute \\
\hline & & Other \\
\hline & Ministry of Culture & \\
\hline & Archeologists & \\
\hline & Amateurs & \\
\hline & Politicians & \\
\hline & Society & \\
\hline & Trust & \\
\hline & Non-Governmental Organization & \\
\hline & Other Sources & \\
\hline \multirow{3}{*}{ Number of people involved } & Less than 2 & \\
\hline & Between 2 and 5 & \\
\hline & More than 5 & \\
\hline
\end{tabular}


Chart 1. General and specific aspects.

Provisional scorecard newspaper analysis

Source diversity

High value source

Data richness

Prioritization

Method

Limitations

Controversy

Contextualization

Investigative Journalism

Collaborative Journalism

Journalist's story

Exclusive interview

Topic

Not a journalist's story but original approach

Original story

Paradigmatic theme

Universal theme

Digital tools

Form

Creative writing

Literary excellence

Aesthetic excellence

\begin{tabular}{|c|c|c|}
\hline \multirow{10}{*}{ Other } & \multirow{3}{*}{ News } & Contextualization \\
\hline & & Background \\
\hline & & Future \\
\hline & Proximity & \\
\hline & Social relevance & \\
\hline & Political & \\
\hline & Economic & \\
\hline & Medical (scientific) & \\
\hline & Social & \\
\hline & Other & \\
\hline \multirow{5}{*}{ Quality of Information } & Sensationalist & \\
\hline & Dissemination & \\
\hline & Programmed & \\
\hline & Public Service & \\
\hline & Other & \\
\hline \multirow{3}{*}{ Type of actors } & Institutional & \\
\hline & Social & \\
\hline & Individual & \\
\hline \multicolumn{3}{|l|}{ Geographical Scope } \\
\hline \multirow{12}{*}{ Headline Analysis } & \multirow{3}{*}{ Headline } & Less than 13 words \\
\hline & & 13 words \\
\hline & & Over 13 words \\
\hline & \multirow{2}{*}{ Present time } & Yes \\
\hline & & No \\
\hline & \multirow{2}{*}{ Negative headline } & Yes \\
\hline & & No \\
\hline & \multirow{5}{*}{ Elements in the headline } & Header \\
\hline & & Kicker \\
\hline & & Headline \\
\hline & & Subhead \\
\hline & & Pull quote \\
\hline \multirow{7}{*}{ Type of headline } & Factual & \\
\hline & Metaphorical & \\
\hline & Descriptive & \\
\hline & Play on Words & \\
\hline & Sensationalist & \\
\hline & Editorial & \\
\hline & Frivolous & \\
\hline
\end{tabular}

Source: Prepared by the authors (2019). 
For the analysis of 150 units, we followed similar researches, such as Costa's (2008) ${ }^{\mathbf{2}}$ and Naranjo's (2011), to study generic parameters (Mena-Young; Aguilera, 2019). The first block analyses the position, length, section, genre, and photography of the news pieces in the papers. The second part assesses the quality of the information in terms of sources, method, form, and headlines. We also applied the recommendations of Elías (2008) regarding genres, who states that journalistic information can come in any format. Similarly, we considered the graphic part: does the information contain visual support? What type of image prevails? Are there charts and illustrations? Photographs are considered an essential element to communicate science. In fact, not only do they illustrate the information in a daily, but also they come to validate theories of importance for the history of humankind. As Canellas (2016) explains, after convincing the editors that an item has to be in the agenda, the most difficult part for the journalist begins: telling the story. Therefore the tool tries to analyze the quality of the information published.

We have used the methodology designed by the Observatory PerCientEx. We applied several criteria to draw a distinction among the literal reproduction of a news item in more than one press vehicle, topics generated by the media itself, and topics that have been addressed in a more careful way, with different sources, providing a context and life stories, with originality and creativity.

We then grouped the "topic" (the main idea), the "method" (the journalistic tools), and lastly, the "form" (the technical and formal tools used and format innovation). All in all, we tried to measure the degree of excellence, that is, of innovation, regarding how the topic was addressed and the richness in data and literature.

To classify scientific information as excellent, we also assessed the multiplicity of sources used, their quality and cross-references to other studies, and reports from other specialized entities as context. Likewise, we considered their degree of social interest, their implications for the future, the physical proximity of what is being presented and the readers, etc.

With this tool for both generic information and excellence, we analyzed all the news items around allergies and prehistory published from January $1^{\text {st }}$ to December $31^{\text {st }} 2018$.

In particular, we looked for items in the printed versions of the dailies "El Mundo", "La Vanguardia", "La Razón", "El País", and "EI $A B C$ ", ranked as the most widely read newspapers in the different editions of the Spanish General Media Report in the last year available (Asociación..., 2018).

In order to retrieve all the published articles on these two topics in these dailies, which present the largest number of readers in Spain, we used the news platform and journalistic documentation tool "MyNews".

Through this archive, accessed in the library of the University of Extremadura, we looked for sources of information filtering the search by the position "full article" and by the section "all". The results showed a total of 1036 pages. The system retrieved 436 items under the search term "allergy", and the 600 others under "prehistory". Then, we divided the items into those where the topics allergies and prehistory were the piece's main theme and those where they were indirectly mentioned.

Using this filter, we finally extracted a total of 67 items related to allergies and 74 related to prehistory. All items were checked against the initial hypotheses: (1) items related to health issues have more impact on the written press than those related to the social sciences; (2) Items on science are scarce in the country's written media; (3) Science is not presented as in-depth information and most of the time, items are not about excellent science.

Of the 141 news items found for the comparison, we selected those whose main goal was communicating results or disseminating scientific findings about allergies (34) and prehistory (19). The rest were considered indirect and only included in the database to retrieve and screen the data and produce background figures.

\footnotetext{
2 The outcomes of this study are presented in Chart 1.
} 


\section{Results}

The results were drawn from the predetermined units of analysis (Chart 1). The data obtained has allowed us to establish a comparison between the total items on allergies versus prehistory, adding direct and indirect pieces. We observed that in 2018, direct items about the latter were superior to the number of pieces about the former, in the direct and indirect news total.

Cross-referencing the data also showed that $41 \%$ of the information on allergies, both direct and indirect, were published by dailies between the months of May and July. It is true, however, that the items concerning this topic are present throughout the study period.

Nevertheless, these newspapers did not use any of their informative spaces to publish items focusing on prehistory until the month of May. If we include the summer months, June to October, we can see that half of the year's output in social science-related themes happens at this time of the year. There is a common denominator in the different types of items analyzed. The newspaper that published more items on both allergies and prehistory is ABC followed by "La Razón". This research compares how, in the case of allergies, both newspapers cover $32.4 \%$ and $29.4 \%$ of all items respectively, and $52.6 \%$ and $21.1 \%$ in the case of prehistory. We analyzed the place direct items on allergies and prehistory occupied in dailies in 2018. Newspapers publish hundreds of items in print, but not all of them are equally important or interesting.

In order to understand the hierarchical organization and relevance of scientific items in these newspapers, we evaluated their distribution in even and odd pages, the latter being the most coveted for advertising as this is where readers first look when they open the newspaper. We have seen that items on allergies (58.8\%) and prehistory (52.6\%) usually appear on even pages. This outcome clearly shows their low place in the dailies' hierarchical structure.

The location of these news items within the daily was also scrutinized. They were usually included in the regional or social pages. Sometimes, the media vehicles also used the science section for this type of information, but this is not done systematically, as it should be. The business pages have been the most widely used section in this regard, rather than the $\mathrm{R}+\mathrm{D}+\mathrm{I}$ (Research+Development+Innovation) section. This is due to the type of approach to the information each item develops. Thus, as many items question the economic impact of the discovery of a new archeological site, those have been commonly placed in the business section.

As for the title page, no items in the study were found in this particular position. We did find two catch lines for allergies on the title page. However, while the newspapers in the study did not often use their highlighting tools to disseminate the information analyzed, it is true that once inside the newspaper, these topics occupied a full page in more than half of the cases (allergies 58.3\% and prehistory 52.6\%). When they shared space with other items, the newspaper gives them relevance by placing information on allergies on the upper part of the page in $41.6 \%$ of cases and in $47.3 \%$ of the cases for prehistory.

The most widely used genres were news and short reports. Of all the items about allergies and prehistory analyzed, these two genres make up almost $40 \%$ and $20 \%$ respectively.

Regarding graphic aspects, items about allergies tend to include photographs to illustrate the information. Medium-size images from several sources and authors were found. Getty Images, a platform for royalty-free stock photographs was used in many cases.

Besides that, in 54\% of cases, the picture included a caption explaining the image. The situation in this case is similar for both topics. Documentary photography is usually found, with some graphs for allergies (2.9\% of cases) and illustrations (20.3\% for allergies and $10.5 \%$ for prehistory). A remarkable aspect has to do with the image size - most of them are large (47.3\%) and include a caption (85.0\%). The most widely used typologies are portraits (37.0\%) and landscapes (26.0\%). However, items on prehistory that presented graphics and illustrations were rare (10.0\% of cases), making it an uncommon tool for this type of information. 
We also studied the degree of journalistic excellence. After all, data alone does not mean much. Journalists have to use metaphors that convey the message of science, they have to be able to interpret graphs, they must give a face to the story they are telling. They have to use all their professional skills in order to reach an audience that is surrounded by an important informational deluge.

Regarding the sources, we saw how, in the case of prehistory, newspapers usually refer to the university and journals to get information. In the case of allergies, the most widely used source were doctors, although they sometimes got statements from university experts through papers or announcements made by institutions relevant to public health, such as hospitals (Figure 1 and 2). In any case, in these two figures (Figure 2 and 3) we can

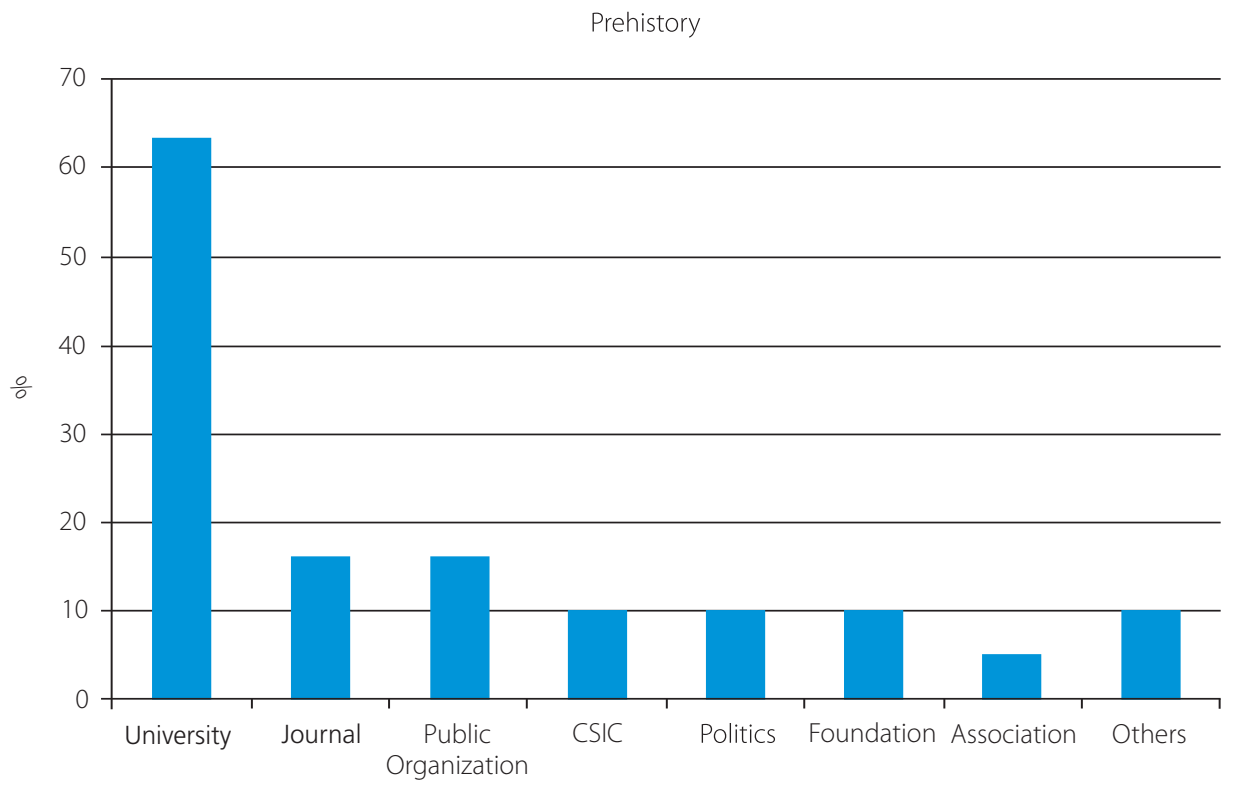

Figure 1. Sources of Information Prehistory.

Note: CSIC: Consejo Superior de Investigaciones Cientificas.

Source: Prepared by the authors (2019).

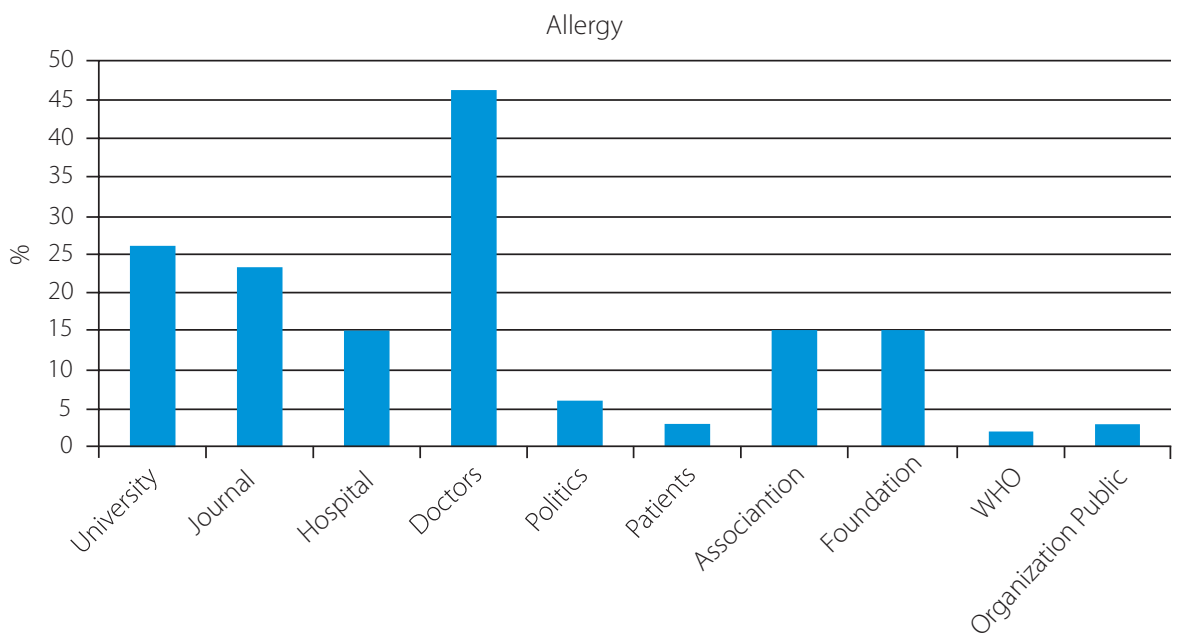

Figure 2. Sources of Information Allergies

Note: WHO: World Health Organization

Source: Prepared by the authors (2019). 
see how allergies employed a larger diversity of sources. This diversity of sources is understood as a positive aspect, as it enriches and complements the snapshot delivered to citizens.

Authors such as Lief (2015) or Molinos (2015) affirm that the task of translating and interpreting science is still a challenge for many journalists, who must leave their comfort zones and tell science stories without necessarily being Professors or hold a PhD. Taking this into account, we decided to analyze the journalists' methods in order to identify good reporting practices.

Contextualization, or diverse and high value sources, is the most remarkable information to extract from this analysis. Figure 3 crosses data obtained from this analysis on both topics. The situation is quite similar for both themes, although prehistory seems to have a higher percentage of high value sources. We see that of all the aspects studied, contextualization, i.e. explaining the topic's background, clarifying what is new and what are the foreseeable repercussions, is the aspect that gets a percentage of $100 \%$ for both topics in our evaluation.

However, almost a third of the total items studied used multiple information and high value sources, both in the academia - allergologists, anthropologists - and outside - doctors, associations, professionals, municipalities, etc.

Moreover, all items, both for allergies and for prehistory, were seen as neutral - there was no ideological nor advertising bias, neither did the journalists try to instill great fear or extreme enthusiasm around the topic through their writing. We also measured the number of times the information becomes the journalist's own topic and, therefore, it is not the direct result of press releases or the journals and institutions' media agenda (Figure 4).

The most remarkable aspect here is the high narrative value of a large share of the information analyzed for the study, reaching 37\% in the case of prehistory and 30\% for allergies. As a general rule, aspects such as social, medical, institutional, or close interests have been constantly found in the study. Of all the elements analyzed, the social value of information was $82 \%$ in allergies and $73 \%$ in prehistory. This is one of the highest values registered in the whole analytical process. This outcome, on the other hand, seems logical as one of the most important pillars of journalism is that a topic is interesting for the citizens. In this sense, it is difficult to understand how items around prehistory are higher in number than those regarding allergies, as there are around 14 million people living with allergies in Spain, thus making it an extremely relevant theme for the population.

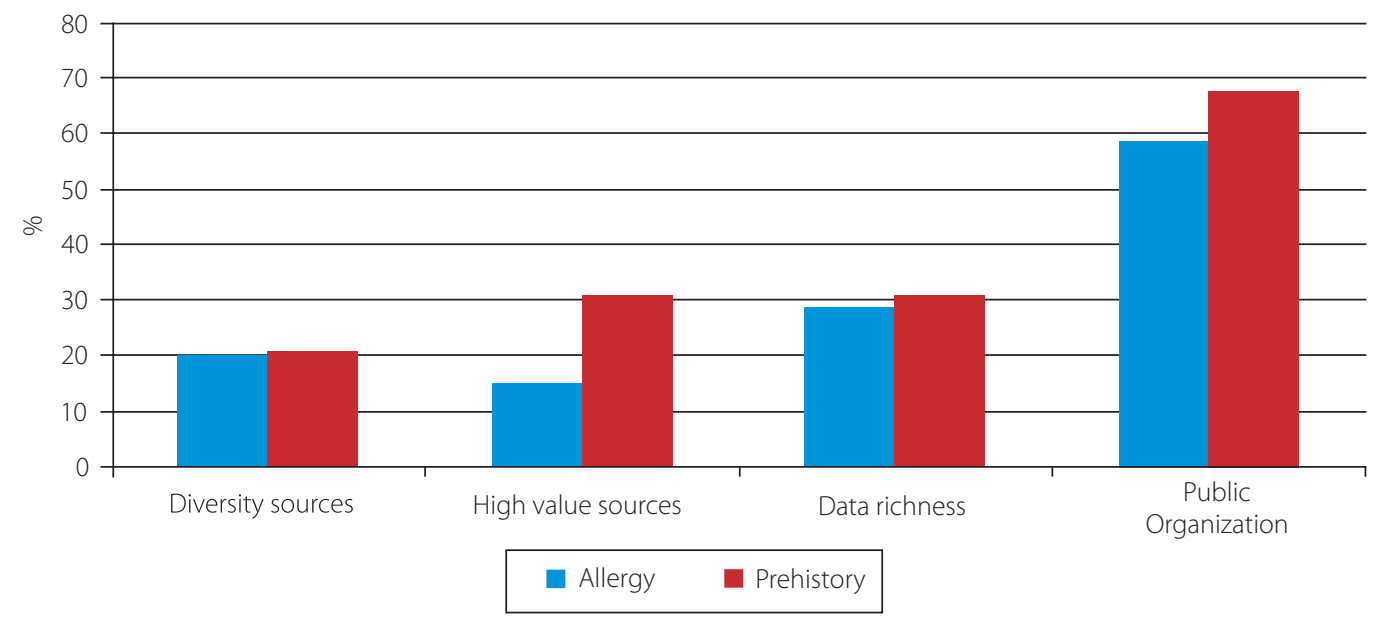

Figure 3. The method Allergies and Prehistory. Source: Prepared by the authors (2019). 


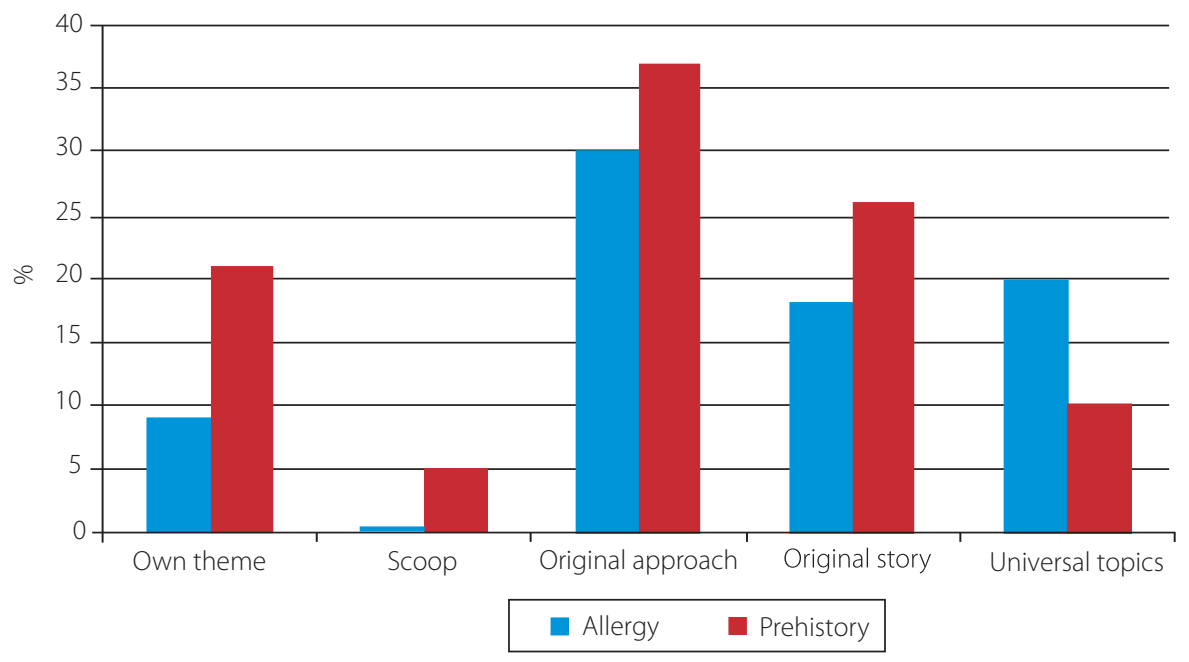

Figure 4. Theme Allergies and Prehistory

Source: Prepared by the authors (2019).

This analysis revealed that most items respond to dissemination purposes (64\% in the case of allergies and $47 \%$ for prehistory). Likewise, the most important actors mentioned are institutions (public or private organizations) rather than social bodies (groups of people) or individuals (personal stories).

\section{Conclusion}

In light of the results obtained, we refuted the first of the three hypotheses. While we had expected items related to health topics to have more impact on the written press than those related to the social sciences, our analysis has shown that the number of items on allergies, both direct and indirect, is lower than that on prehistory. Hypothesis two has been confirmed. Dailies publish hundreds of items every day, but the number of items that focus on disseminating or communicating science is negligible. We registered 141 items where allergies and prehistory are directly or indirectly addressed, a low figure from our perspective, given the interest and degree of relevance for citizens.

Besides, as we mentioned in the third hypothesis, it is difficult to qualify the items found as excellent science. Be it in terms of the topic, the method or the form, the percentages achieved in our evaluation are quite low, despite the fact that most of these news items focus on scientific topics that interest and affect large groups of citizens. Our general conclusions focus on two aspects: generic reflections regarding the way science as a whole is reported in the media, and others about the differences between addressing health or social topics in the news.

We conclude that science information is not only presented in supplements. Increasingly, what happens in research and in labs is mainstreamed in the written press. However, although both allergies and prehistory are matters of social relevance, their presence in the news is scarce. This type of information is found on even pages, thus signaling its small importance and advertising costs, as readers do not read these pages first. The newspapers in question treat both themes in the same way. Most news items around allergies and prehistory were found in the newspapers "El $A B C$ " and "La Razón". However, catch lines or back page space was not used even by these two dailies for information.

Although these items often occupy a full page, they always include publicity, usually placed on top of the item, while a short report is the second most widely used genre for both themes. Both topics are most usually 
categorized as news, as there is no informative depth as required by other formats. This might be due to another aspect found in the study: the journalists in charge of those areas are replaced all the time. Every single item, except for those issued by agencies, has been written by a different journalist. This shows a gap in the specialization needed for scientific journalism to play a significant role in a knowledge-based society. We also highlight the role of photography, a widely used resource for both themes. Also, graphs and illustrations must be considered as high value resources when explaining difficult scientific concepts, especially for prehistory, as $10 \%$ of the direct items on allergies analyzed did include some visual support.

Regarding the sources, doctors tend to be the main sources for allergies, although scientific journals and university experts can be found in both themes. In prehistory, however, other sources, such as universities and journals, are the most important sources in the list due to their high value. If we go deeper into the analysis of reporting and quality, our study did not find any bias in how the information was reported. In both allergies and prehistory the journalistic approach is key. The headlines for those topics' news items are informative in nature and fall into the category described by Costa (2008) as dissemination/informative; they stay away from sensationalism or interpretation.

Sometimes journalists try to be creative, especially by employing an original approach to the information, or else by choosing the themes on their own, without following the media or institutional agenda. However, institutional agents are the most frequently found voices in this type of items, maybe because they are seen as high value sources and because journalists are not just trying to contextualize the information but also to bring the item closer to citizens and social concerns.

\section{Contributors}

M. P. CUÉLLAR performed field work, methodological design, extraction of conclusions, review, writing, and follow-up. D. M. PENA worked with field access, methodology, and results and conclusions. A. V. MORENO prepared and supervised the research methodology and conclusions.

\section{References}

Alcalde, J. ¿De dónde viene la expresión a hombros de gigantes? La Razón, Madrid, 20 out, 2018. Disponible en https://www. larazon.es/cultura/de-donde-viene-la-expresion-a-hombrosde-gigantes-LD20238740. Acceso: 28 dic. 2019.

Alonso, J; Eleazar, A; Moreno, C. La publicación de noticias sobre los resultados de I+D+i: ¿cómo es percibida por los investigadores españoles? InMediaciones de la Comunicación, v. 13, n. 2, p. 115-140, 2018.

Alonso, M. La comunicación científica en la prensa digital española: radiografía de sus fuentes informativas. Communication Papers: Media Literacy \& Gender Studies, v. 7, n. 13, 2018.

Asociación para la Investigación de Medios de Comunicación. Spanish General Media Report. Madrid: AIMC, 2018. Disponible en: http://reporting.aimc.est. Acceso en: 1 ene. 2018.

Bellón, A. Gabinetes de comunicación del Sistema de Ciencia, Tecnología e Innovación: el puente que cruza la I+D para llegar a los medios. Communication Papers: Media Literacy \& Gender Studies, v. 7, n. 13, p. 237-252, 2018.
Berelson, B. Content analysis in comunication research. Glencoe: Free Press, 1952.

Calvo, A. Comunicación de la ciencia hoy: una visión personal y un decálogo añadido. Revista de Medicina, Lenguaje y Traducción, v. 16, n. 42, p. 134-141, 2015.

Canellas, M. Periodismo científico, el puente entre el laboratorio y la sociedad. adComunica: Revista Científica de Estrategias, Tendencias e Innovación en Comunicación, n. 4, p. 229-234, 2016.

Casino, G. Cita periodística. Impacto de las revistas y los artículos científicos en la prensa generalista. El Profesional de la Información, v. 27, n. 3, p. 692-697, 2018.

Cassany, R; Cortiñas, S; Elduque, A. Comunicar la ciencia: el perfil del periodista científico en España. Comunicar, n. 55, p. 9-18, 2018. Doi: https://doi.org/10.3916/C55-2018-01.

Costa, C. Medicina y salud en la prensa: las noticias de salud en los principales diarios de Galicia. Revista Latina de Comunicación Social, v. 63, p. 15-21, 2008. Doi: https://doi. org/10.4185/RLCS-63-2008-750-015-021. 
De Semir, V. Decir la ciencia. Barcelona: Universidad de Barcelona, 2015.

Elías, C. Fundamentos de periodismo científico y divulgación mediática. Madrid: Alianza Editorial, 2008.

Elías, C. Science on the ropes: decline of scientific culture in the era of fake news. Madrid: Springer, 2019.

España. Fundación Española para la Ciencia y Tecnología. Encuesta de percepción social de la Ciencia y la Tecnología. Madrid: Fundación Española para la Ciencia y Tecnología, 2018.

Fernández, A. La información científica en la prensa de referencia: el caso español a partir de un análisis comparative. Zer, v. 19, p. 205-232, 2005

Ferrer, A. Periodismo científico y desarrollo: una mirada desde América Latina. Tesis - (Doctorado). Universidad Autónoma de Barcelona, Barcelona, 2002.

Grande, A. et al. Ciencia y Medios de comunicación. Aularia: Revista Digital de Comunicación, v. 5, n. 2, p. 53-64, 2016.

Krtalic, M.; Hasenay, D. Los periódicos como una fuente de información científica en las ciencias sociales y las humanidades: un caso de estudio de la Facultad de Filosofía, Universidad de Osijek, Croacia. In: IFLA World Library and Information Congress, 78., 2012, Helsinki. Anales [...]. Helsinki: IFLA, 2012.

Lief, L. Science meet journalism, you should talk. Revista AEON, 2015. Disponible em: https://wilsonquarterly.com/quarterly/ spring-2015-american-fissures/science-and-innovation-inchanging-newsroom/. Acceso: 2 dic. 2019.

López, X.; Otero, M. L.; Calvo, M. D. El despertar de la infografía en la prensa escrita: el caso de La Voz de Galicia. Estudios sobre el Mensaje Periodístico, p. 329-344, 2008.

Márquez, V. Los contenidos sanitarios en la prensa nacional. Revista Española de Comunicación en Salud. v. 1, n. 2, p. 164-171, 2010.
Martínez, M.; Saperas, E.; Carrasco, A. Communication research in Spain over the past 25 years (1990-2014): objects of study and research methods in the papers published by Spanish peer-reviewed communication journals. Empiria: Revista de Metodología de Ciencias Sociales, n. 42, 2019.

Mena-Young, M.; Aguilera, M. El periodismo científico en grandes reportajes escritos: un estudio a partir de los diarios La Nación de Costa Rica, El País de España y El Universal de México. Estudios sobre el Mensaje Periodístico, v. 25, n. 2, p. 943-960, 2019. Doi: https://doi.org/10.5209/esmp.64818.

Naranjo, A. Tratamiento de la información deportiva en la prensa: la crónica como género prevalente. Tesis - (Doctorado). Universidad de Málaga, Málaga, 2011.

Organización de las Naciones Unidas. Declaración Universal de Derechos Humanos. Adoptada y proclamada por la Asamblea General en su resolución 217 A (III), de 10 de diciembre de 1948. Paris: ONU, 1948. Disponible en: https://www.refworld. org.es/docid/47a080e32.html. Acceso: 13 ene. 2018.

Parejo, M.; Vivas, A.; Martín-Pena, D. Divulgación científica y función social en las universidades. Madrid: Editorial Pirámide, 2018.

Piñuel J. L. Epistemología, metodología y técnicas del análisis de contenido. Estudios de Sociolingüística, v. 3, n. 1, p. 1-42, 2002.

Revuelta, G. Tratamiento periodístico de la ciencia en la prensa. In: Moreno, C. Periodismo y divulgación científica: tendencias en el ámbito Iberoamericano. Madrid: Biblioteca Nueva, 2011.

Ribera Molinos, A. Ciencia y periodismo, una relación a construir. Cuaderno de Cultura Científica, 2015. Disponible en: https:// culturacientifica.com/2015/03/05/ciencia-y-periodismo-unarelacion-a-construir/ Acceso: 22 nov. 2019.

Rodríguez-Tajuelo, M. La percepción social de la arqueología en España a través de los medios de comunicación: los descubrimientos en la prensa escrita hasta 1925. 2016. Tesis - (Doctorado). Universidad Autónoma de Madrid, Madrid, 2016. 